\title{
REMARKS AT THE SYMPOSIUM IN HONOUR OF \\ THE HonOURable Jean Edouard LÉON CôTÉ IN RECOGNITION OF HIS HONOURARY DOCTORATE FROM THE UNIVERSITY OF ALBERTA
}

\author{
The Honourable Chief Justice of Alberta \\ CATHERINE A. FRASER ${ }^{*}$
}

On 14 August 1940, a gorgeous Edmonton summer day, a baby boy was born at the old Misericordia Hospital. And quickly baptized. Whether it was because he was ill, we do not know. What we do know now is that this baby, christened Jean Edouard Léon Côté, was destined for greatness and would go on to become one of this country's true judicial giants. According to Jean: "My paternal grandmother, Cecile Côté, opened a bottle of champagne to celebrate my birth. She had kept that champagne upright for years, not realizing it needed to be stored sideways. So when she opened it, it had lost its fizz. That's the story of my life — no fizz."

$\mathrm{Au}$ contraire. The record proves beyond a reasonable doubt that in his service to Canadians, the Honourable Jean Côté achieved the gold standard of excellence. Indeed, he is the gold standard. As a brilliant legal scholar and one of this country's leading jurists, Jean represents the best the legal profession can produce. His intellect is superior; his work ethic incomparable; and his service record sterling. Altogether that has meant a lot of fizziness along the way. How appropriate that his alma mater — to which Jean has brought great honour and distinction - has seen fit to confer on Jean an Honourary Doctorate of Laws.

Jean is a direct descendant of Jean Côté who sailed from Dieppe in May 1634. Fast forward 200-plus years. Jean's grandfather, Jean Leon Côté, was working in the Yukon as a surveyor. As the gold rush was winding down, he analyzed where the best place to live in Canada would be. He decided Edmonton was the logical choice based on Alberta's natural resources and — don't laugh — the weather! Settling in Edmonton, he married Jean's grandmother, Cecile. They had five boys, including Jean's father, Jean Gustave Côté, the eldest.

When Jean's grandfather died young, Jean's father left school to help support the family. He became a stenographer for the Canadian National Railway and married a young librarian, Cecelia Taylor. While Jean's parents did not have a lot of money, what they did have were strong values they impressed on Jean, values he has carried with him throughout his life integrity, hard work, commitment to family, love of learning, and devotion to duty.

In the 105-year history of the Court of Appeal, only a few lawyers have ever been appointed directly to the Court. Jean Côté is one of them. In his 28 years on the Court, he had a hand in virtually every aspect of this Court's work. Court procedures; practices; list

Chief Justice of Alberta, and Chief Justice of the Northwest Territories, and Nunavut Courts of Appeal. Chief Justice Fraser has been actively involved in judicial education efforts throughout Canada and internationally on a wide range of topics including human rights, judicial awareness training, judicial independence, the application of international treaties domestically, the evolution of equality jurisprudence, and family law. Her remarks herein are a condensed version of those originally given. 
management; case management; strategic planning; Rules of Court; articling students; mentoring — you name it; Jean did it all extraordinarily well. And when it came to our primary duty, deciding cases, Jean was in a league all his own.

It is difficult to do justice to Jean's contribution as judgment writer. With his encyclopedic knowledge of the law, Jean always seemed to know if a point of law had been decided anywhere in the common law world. And if so, where. The prodigious quantity of his work - he wrote almost 1,700 judgments — was matched by its exceptional quality. Jean wrote leading judgments in all areas of the law. You will shortly hear about his contributions in tort law, civil procedure, and contract law. I would explain the larger context of his life's work this way.

Jean's mission has been to do justice in accordance with the rule of law. This invisible force protects everything we enjoy in life. Law and facts collide. People and interests are in conflict. Judges must try to make sense of it all. Jean's approach to judging reflected a deep understanding of the limits of the appellate role; the vital importance of stability in the law; and, above all, that as a matter of logic and policy, the law in a given area should all fit together. While Jean deeply respects the arc of legal history, he has never been a hostage to it. Rather, he saw the wisdom of our predecessors as a basis on which to build up the rights and freedoms of individuals in modern society.

Jean's judgments have touched the lives of everyone here today. In tort law, Jean did his best to rationalize disparate theories on where tort law should be going. And he exercised caution in defining both the relationships that give rise to a duty of care and how far to throw the foreseeability net. In civil procedure, Jean towered over the evolution of the law. As chair of the Rules of Court Committee for almost two decades, he understood very well that the Rules are merely a means to an end. In other words, litigants should not be able to use the Rules to delay dealing with the substance of the case. As for contract law, Jean understood that, subject to defined limits, freedom of contract remains a key principle of the common law. His judgments underscored the importance of certainty and the strong policy reasons for allowing contracting parties, especially in commercial matters, to set the terms governing their relationship.

In constitutional law, Jean recognized that division of powers means just that - power is divided and provinces actually have some powers into which the federal government cannot properly intrude. And that the Charter protects not only certain individual rights but other rights too, including equality rights. And that when rights collide, one right does not automatically trump another. Jean has also had a strong influence in criminal law and sentencing. His sentencing judgments, grounded in Parliament's overarching sentencing principle and rejection of the unfairness inherent in judge shopping, often delved deeply into where to draw the proper line in sentencing and why.

Colleague Jack Watson put it best: "Jean was meticulously engaged with getting the law right. Jean knew that the more persuasive the common law is, the more impact it has - and as an appellate judge, he wanted to say something that the people of Canada could not only believe, but believe in." 
As for Jean's writing style, no one writes in Jean's voice. It's highly distinctive - clear, concise, and colourful - and packed with reasoning grounded in logic. As in, if this, then that — and if that, then a problem — and a big one — and so, I'm not going there. As Justice Frans Slatter has said, "You always know when you've got a Côté judgment. It's like looking at a Picasso: there's never any doubt about who the artist was." Jean's judgments are replete with similes, metaphors, and allusions - and logic examples - to which everyone can relate. They reflect Jean's key point about legal writing: "If you can't explain your argument to your next-door neighbour, you don't understand your own argument." To ensure the reader understood what he was saying, Jean used colourful turns of phrase which linked legal principles to a diverse array of objects, events, and creatures.

Backwards reasoning, cats' paws, and especially dogs' tails figured prominently in Jean's judgments. Examples: "[H]ere the tail wags the dog." ${ }^{\text {Or }}$ "The tail may do more than wag the dog; it may be chasing the dog in circles." $\mathrm{Or}$ "The tail is not only wagging the dog, but is growing larger than the dog." ${ }^{3}$ In one case, when a person claimed to have spent $\$ 269,000$ in one year on intangibles without any evidence by way of credit card or cheques, Jean wrote: "That averages over $\$ 730$ a day, every day of every week. No man's bar tabs, restaurant bills or opera tickets can steadily come to that, even if washed down with Veuve Clicquot." In another case, a telecommunications company argued it should be entitled to charge for a 911 service in the North even though it provided none. Jean wrote: "It is like delivering to a starving person a photograph of a turkey dinner, and then charging him or her for a turkey dinner (or delivery of one)."

Jean's questioning style in court can be summed up in six words: Let me give you an example. As the master of the hypothetical, the minute Jean leaned back, put his hands together in a teepee, and said, "OK, counsel, let's suppose that," counsel knew they were in for a true challenge. By the time Jean got through everything he wanted them to assume in answering his question probing the logic of their reasoning, they sometimes lost their train of thought. I must confess that by the time Jean, with his beautiful mind, finished with his assumptions, we, his colleagues on the panel, sometimes lost ours too.

Jean is a born teacher. From the time he was a young lawyer to this day, he has taught and mentored generations of lawyers, students, and judges. I believe one reason Jean is so successful is that he's a master of trivia. He knows so much about so many subjects: economics, geography, politics, history, and movies. He realizes that to understand the future, one must know the past. He's an expert on military history. Jean's also an unrivaled film buff. Ask Jean if he knows any good movies, and you will be handed a list entitled "Over 1,000 Films which the Côtés Recommend" along with a treasure trove of his review entries.

Ernest Hemingway once said, "For a true writer each book should be a new beginning where he tries again for something that is beyond attainment. He should always try for

$R v$ Merchant, 1991 ABCA 115 at para 8.

Ibid.

KDM Management $v$ Rushton, 1998 ABCA 217 at para 33.

$R v$ Fulcher, 2007 ABCA 381 at para 25.

Bell Mobility Inc v Anderson, 2015 NWTCA 3 at para 64. 
something that has never been done or that others have tried and failed. Then sometimes, with great luck, he will succeed." ${ }^{\prime 6}$ By this standard, Jean has succeeded nine straight times. His legacy includes the first modern Canadian text on the law of contracts written when he was just a young lawyer. Jean is perhaps best known for co-authoring, along with his longtime friend, Bill Stevenson, the Civil Procedure Encyclopedia - known as "Stevenson \& Côté" - a comprehensive guide to legal practice in Alberta. The current edition consists of 82 chapters in five volumes, listing over 39,000 judgments and referencing 80,000 or more citations from texts and articles. ${ }^{7}$ And he has written two of the only books in Canada on appellate judging. To give you some idea of Jean's dedication, one of his most recently published books, Words that Bind, took over 40 years to write and contains some 32,000 entries! ${ }^{8}$

It has been my great privilege to have worked closely with the Honourable Jean Côté for almost a quarter of a century. During his time on the Appeal Court, Jean never lost his enthusiasm for his work. Not once. He ran full speed through the tape at the finish line, issuing his last judgment on his last day as a judge. Please join me in thanking the Honourable Jean Côté, an extraordinary judge and extraordinary person, for his formidable, faithful, and fearless service to Canada — and to justice for all. online: $<$ https://www.nobelprize.org/prizes/literature/1954/hemingway/speech/>. 